\title{
THE INFLUENCE OF BIOSTIMULANTS AND FOLIAR FERTILISERS ON THE PROCESS OF BIOLOGICAL NITROGEN FIXATION AND THE LEVEL OF SOIL BIOCHEMICAL ACTIVITY IN SOYBEAN (GLYCINE MAX L.) CULTIVATION
}

\author{
NiEWIAdOMSKA, A. ${ }^{1}$ - SULEWSKA, H. ${ }^{2}$ - WOLNA-MARUWKA, A. ${ }^{1}$ - RATAJCZAK, K. ${ }^{2}$ - \\ WARACZEWSKA, Z. ${ }^{1}$ - BUDKA, A. ${ }^{3}-$ GŁUCHOWSKA, K. ${ }^{1}$ \\ ${ }^{I}$ Department of General and Environmental Microbiology, Poznań University of Life Sciences, \\ ul. Szydłowska 50, 60-656 Poznań, Poland \\ ${ }^{2}$ Department of Agronomy, Poznań University of Life Sciences, ul. Dojazd 11, 60-632 Poznań, \\ Poland \\ ${ }^{3}$ Department of Mathematical and Statistical Methods ${ }^{3}$, Poznań University of Life Sciences, ul. \\ Wojska Polskiego 28, 60-637 Poznań, Poland \\ *Corresponding author \\ e-mail: alicja.niewiadomska@up.poznan.pl
}

(Received $13^{\text {th }}$ May 2019; accepted $16^{\text {th }}$ Jul 2019)

\begin{abstract}
The aim of this study was to assess the influence of selected biostimulants (Tytanit, Rooter) and foliar fertilisers (Optysil, Metalosate Potassium, Bolero Bo, ADOB 2.0 Zn IDHA, ADOB B, ADOB $2.0 \mathrm{Mo}$ ) on the activity of dehydrogenases, acid and alkaline phosphatases and catalase, and their influence on the level of biological nitrogen fixation based on the nitrogenase activity in soybean cultivation. Between 2016 and 2018 a field experiment was conducted at the Gorzyń Experimental and Educational Station, Poznań University of Life Sciences in Poland. During the three years of the experiment the foliar fertilisers and biostimulants significantly stimulated the catalytic dehydrogenase activity (DHA) and alkaline phosphatase activity (PAL) in all the experimental variants, as compared to the control variant. The analysis of the results of acid phosphatase activity (PAC) during the entire soybean growing period showed that it decreased significantly compared to the control variant when Tytanit, Rooter and Bolero Mo preparations were applied. Additionally, the analysis of catalase activity (CAT) revealed that apart from Tytanit, all the preparations significantly stimulated this enzyme, as compared with the control variant. The field analyses of biological nitrogen fixation showed that the fertilisers and biostimulants significantly stimulated nitrogenase activity under the soybean plantation.
\end{abstract}

Keywords: dehydrogenase activity, phosphatase activity, catalase activity, nitrogenase activity, BIF

\section{Introduction}

In recent years agrotechnical treatments with pesticides as well as phosphorus and nitrogen fertilisation have become a threat to all elements of the ecosystems (Nardi et al., 2016). New sustainable, cost-effective and environment-friendly cultivation technologies that ensure high yield and quality of crops are being sought to limit the negative influence of these treatments on the soil environment (Vernieri et al., 2006). The application of environment-friendly practices is dictated by European Union law (EU Directive 2009/128) and recommendations concerning integrated protection/cultivation which have been in effect, in Poland since 2014. Moreover, due to the feed protein deficit in Europe and Poland (Borowska et al., 2016) there is a pressing need to search for opportunities to increase the yield of crops, especially legumes, which are a valuable sources of protein. 
Legumes are becoming increasingly important in sustainable agriculture (Massawe et al., 2016). What speaks in favour of their cultivation is the fact that they improve the physicochemical properties of soil, enrich organic matter content by leaving large amounts of crop residue and reduce the consumption of nitrogen fertilisers. Soybean (Glycine $\max$ L.) is one of the most important crops in this group. Its seeds contain about $40 \%$ of protein with a favourable amino acid composition and $20 \%$ of fat, with the predominant share of unsaturated fatty acids. The cultivation of soybean is gaining popularity in Poland as a result of the changing climate and the introduction of new varieties (Gaweł, 2011; Florek et al., 2012; Stagnari et al., 2017).

One of the metabolic features of legumes is their ability to coexist with bacteria that fix atmospheric nitrogen (diazotrophy process) (Poole et al., 2018). As the content of valuable protein in a plant depends on the system formed between the plant and rhizobia, it seems right to look for agents that increase the efficiency of this symbiosis.

Biostimulants, which are defined as materials containing one or more active substances and/or microorganisms, are gaining increasing attention in scientific circles. They increase the uptake of nutrients by plants and tolerance to abiotic and biotic stress and they improve the yield quality (Calvo et al., 2014). Biostimulants can also stimulate the activity of rhizosphere microorganisms and soil enzymes, the production of hormones and increase photosynthesis (Giannattasio et al., 2013).

Intensified cultivation has caused foliar fertilisation to become an indispensable agrotechnical treatment. Among the large number of nutrients that are necessary for the proper growth of plants, some must be supplied in larger quantities, while others - in smaller or even trace amounts. Plants exhibit the highest demand for potassium and nitrogen (more than $200 \mathrm{~kg}$ when the yield per 1 ha is calculated), while they need only small amounts of zinc, boron, copper and molybdenum (only a few grams when the yield per 1 ha is calculated). This shows that foliar fertilisation is particularly effective when micronutrients need to be supplied to crops. In some situations, it is also recommended that macroelements such as nitrogen, and magnesium, and less frequently phosphorus, potassium, sulphur and calcium, should be sprayed onto leaves (Szewczuk and Sugier, 2009).

Each of the agrotechnical treatments applied to crops, i.e. fertilisers or biostimulants, may lead to changes in the soil environment. Many studies have shown the diverse effects of these treatments on the populations of selected groups of microorganisms and the level of soil enzymes they secrete (Karaca et al., 2010).

The determination of the biochemical activity of soil based on the activity of soil enzymes is an important tool in helping to assess soil quality. Enzymes are considered to be good and sensitive indicators because they quickly react to changes in the soil caused by natural and anthropogenic factors. Furthermore, they are easy to measure and their activity determines the main microbiological reactions occurring in the cycles of nutrients in the soil (Nannipieri et al., 2002; Karaca et al., 2010). Studies have shown that agrotechnical treatments affect enzymatic activity more than other biochemical parameters (Saviozzi et al., 2001).

The aim of this study was to assess the influence of selected biostimulants (Tytanit, Rooter) and foliar fertilisers (Optysil, Metalosate Potassium, Bolero Bo, ADOB 2.0 Zn IDHA, ADOB B, ADOB $2.0 \mathrm{Mo}$ ) on the activity of dehydrogenases, acid and alkaline phosphatases and catalase, and their influence on the level of biological nitrogen fixation based on the nitrogenase activity in soybean cultivation. 


$$
-12651 \text { - }
$$

\section{Materials and methods}

Between 2016 and 2018 a field experiment was conducted at the Gorzyń Experimental and Educational Station, Poznań University of Life Sciences. The GPS coordinates of the experiment at the Gorzyń Station were as follows: N-52.56589, E015.90556, $65 \mathrm{~m}$ AMSL. Each year one-factor experiments were conducted as randomised block design in four replications, with following nine factor levels: 1. control variant -not treated plants; 2. Tytanit; 3. Optysil; 4. Metalosate Potassium; 5. Rooter; 6. Bolero Mo; 7. ADOB Zn IDHA; 8. ADOB B; 9. ADOB 2.0 Mo (Fig. 1).

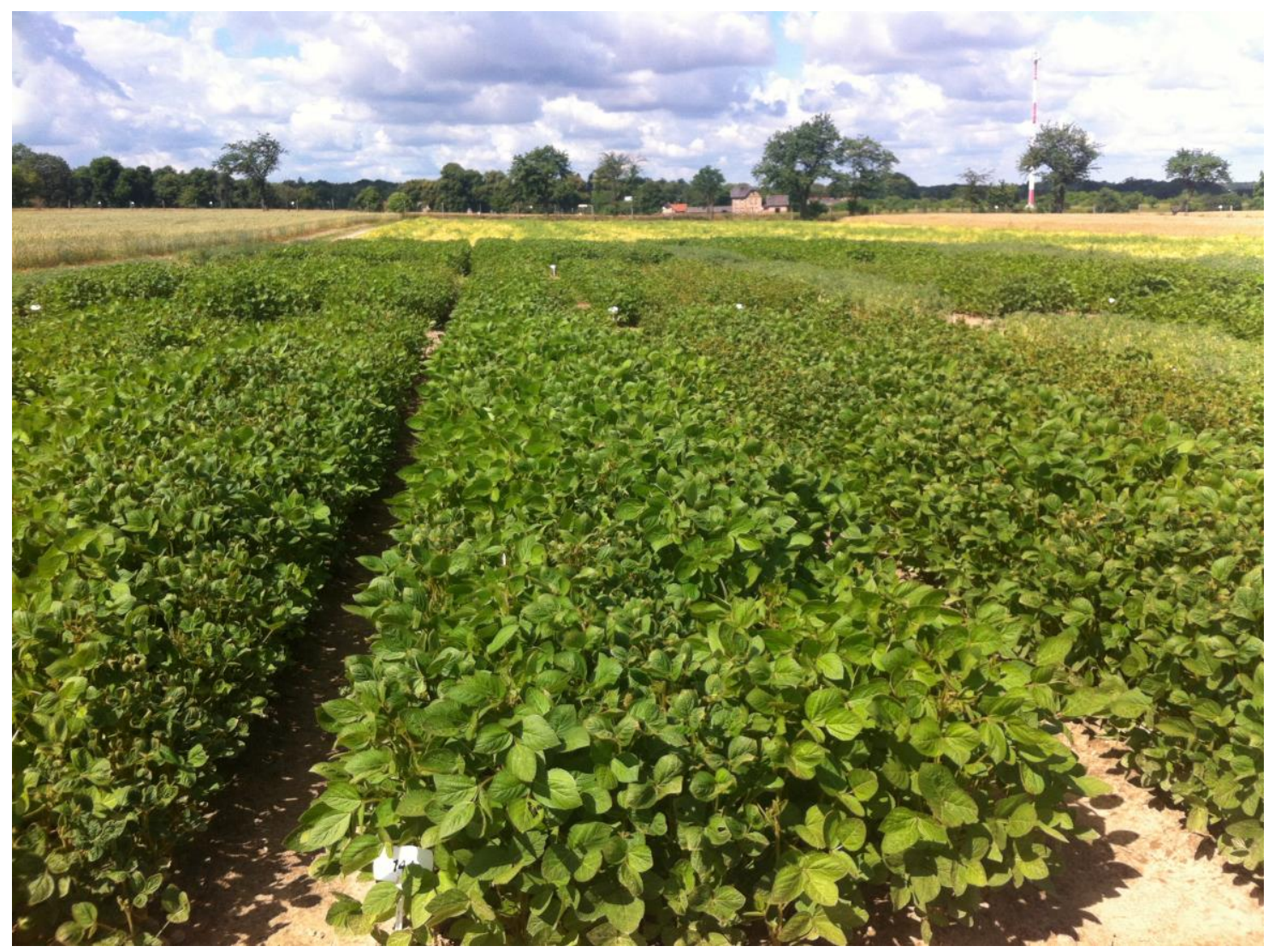

Figure 1. Experimental culture at the plants' full growth (BBCH 35-40)

Each fertiliser was applied in a timely manner, according to the manufacturer's recommendations (Table 1).

Soybean seeds, Merlin cultivar (SAATBAU) were used in the experiment. When seeds of this cultivar are purchased, they are already encapsulated with rhizobia of the Bradyrhizobium genus together with the polymer, which also acts as a preservative and protects the bacteria from sunlight.

The Merlin cultivar can be grown all over Poland. It is characterised by high yield (from $2.4 \mathrm{t} \mathrm{ha}^{-1}$ on poor quality soils up to $3.2 \mathrm{t} \mathrm{ha}^{-1}$ on good and very good quality soils), high resistance to lodging and high regeneration capacity.

The seeds were sown (25 $5^{\text {th }}$ April 2016, $24^{\text {th }}$ April 2017 and $20^{\text {th }}$ April 2018), on plots with an area of $21 \mathrm{~m}^{2}$, with a distance between rows of $15 \mathrm{~cm}$, and sowing density was 90 seeds per $1 \mathrm{~m}^{2}$. 


$$
\text { - } 12652 \text { - }
$$

Table 1. The terms and doses of biostimulants and fertilisers applied in the experiment

\begin{tabular}{|c|c|c|c|}
\hline \multicolumn{2}{|c|}{$\begin{array}{c}\begin{array}{c}\text { Biostimulants/foliar } \\
\text { fertilisers }\end{array} \\
\end{array}$} & \multirow[b]{2}{*}{$\begin{array}{c}\text { Term and dose of biostimulant } \\
\text { I: leaf and shoot development (BBCH 13-29) - } \\
0.3 \mathrm{dm}^{3} \mathrm{ha}^{-1} \\
\text { II: inflorescence development (BBCH 51-59) - } \\
0.3 \mathrm{dm}^{3} \mathrm{ha}^{-1} \\
\text { III: beginning of pod development (BBCH 71) - } \\
0.3 \mathrm{dm}^{3} \mathrm{ha}^{-1}\end{array}$} & \multirow{2}{*}{$\begin{array}{c}\text { Fertiliser characteristics } \\
\text { Liquid, mineral stimulant containing } \\
\text { titanium (Ti). It increases the yield } \\
\text { volume and development of plants, } \\
\text { improves yield quality parameters and } \\
\text { increases plants' natural resistance to } \\
\text { stress factors. } \\
\text { Composition: } 8.5 \mathrm{~g} \mathrm{Ti}\left(\mathrm{dm}^{3}\right)^{-1}\end{array}$} \\
\hline 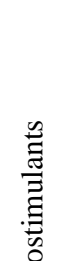 & Tytanit & & \\
\hline$\ddot{n}$ & Rooter & BBCH 13-14 - $1 \mathrm{dm}^{3} \mathrm{ha}^{-1}$ & $\begin{array}{l}\text { Biostimulant - it stimulates the growth of } \\
\text { the root system, accelerates regeneration } \\
\text { and improves the uptake of soil minerals. } \\
\text { Composition: } \mathrm{P}_{2} \mathrm{O}_{5} 13.0 \% ; \mathrm{K}_{2} \mathrm{O} 5.0 \%\end{array}$ \\
\hline \multirow{6}{*}{ 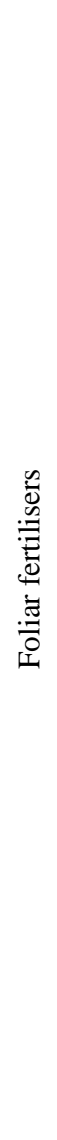 } & Optysil & \begin{tabular}{|l|} 
I: leaf and shoot development (BBCH 15-29) - \\
$0.5 \mathrm{dm}^{3} \mathrm{ha}^{-1}$ \\
II: inflorescence development (BBCH 51-55) - \\
$0.5 \mathrm{dm}^{3} \mathrm{ha}^{-1}$ \\
III: beginning of pod development (BBCH 71- \\
73) - $0.5 \mathrm{dm}^{3} \mathrm{ha}^{-1}$ \\
\end{tabular} & $\begin{array}{l}\text { Liquid, silicon antistressor stimulating the } \\
\text { growth and development of plants, } \\
\text { activating their natural immune systems } \\
\text { and increasing tolerance to unfavourable } \\
\text { cultivation conditions. } \\
\text { Composition: } 200 \mathrm{~g} \mathrm{SiO}_{2}\left(\mathrm{dm}^{3}\right)^{-1} \\
\end{array}$ \\
\hline & $\begin{array}{l}\text { Metalosate } \\
\text { Potassium }\end{array}$ & $\begin{array}{l}\text { 2-3 treatments every } 10-14 \text { days during } \\
\text { intensive growth }-3 \mathrm{dm}^{3} \mathrm{ha}^{-1}\end{array}$ & $\begin{array}{c}\text { Liquid foliar fertiliser containing an easily } \\
\text { absorbable form of potassium, which } \\
\text { supplements potassium deficit in plants } \\
\text { with amino acids. } \\
\text { Composition: } \mathrm{K}_{2} \mathrm{O} 24 \%\end{array}$ \\
\hline & Bolero Mo & Before florescence - $1.5 \mathrm{dm}^{3} \mathrm{ha}^{-1}$ & $\begin{array}{l}\text { Liquid foliar fertiliser containing boron } \\
\text { and molybdenum to supplement the } \\
\text { deficit of these elements in plants. } \\
\text { Composition: B } 8.2 \% \text {; Mo } 0.8 \%\end{array}$ \\
\hline & $\begin{array}{l}\text { ADOB } 2.0 \mathrm{Zn} \\
\text { IDHA }\end{array}$ & Before florescence - $1 \mathrm{dm}^{3} \mathrm{ha}^{-1}$ & $\begin{array}{c}\text { Foliar fertiliser containing zinc (Zn) fully } \\
\text { chelated by biodegradable chelating agent } \\
\text { IDHA. } \\
\text { Composition: } \mathrm{Zn} 100 \mathrm{~g} \mathrm{~kg}^{-1} \text { (weight } \\
\text { percentage content } 10, \text { chelated by IDHA) }\end{array}$ \\
\hline & ADOB B & $\begin{array}{l}\text { I: before florescence }-2 \mathrm{dm}^{3} \mathrm{ha}^{-1} \\
\text { II: after florescence on pods }-1 \mathrm{dm}^{3} \mathrm{ha}^{-1}\end{array}$ & $\begin{array}{l}\text { Liquid, highly concentrated foliar } \\
\text { fertiliser containing boron that regulates } \\
\text { auxin activity and participates in cell } \\
\text { division. } \\
\text { Composition: } \mathrm{N} 78 \mathrm{~g} \mathrm{~kg}^{-1} \text {; B } 150 \mathrm{~g} \mathrm{~kg}^{-1}\end{array}$ \\
\hline & ADOB $2.0 \mathrm{Mo}$ & Early stages of development $-0.15 \mathrm{dm}^{3} \mathrm{ha}^{-1}$ & $\begin{array}{l}\text { Liquid, single-component fertiliser which } \\
\text { increases the rate and efficiency of use of } \\
\text { nitrogen by plants and improves } \\
\text { interaction with iron. } \\
\text { Composition: Mo } 20 \%\end{array}$ \\
\hline
\end{tabular}

According to the FAO/WRB classification [IUSS Working Group WRB], the soil in the experimental plots is a typical luvisol soil formed from light loamy sands, deposited in a shallow layer on light loam (Haplic Luvisols) (Table 2). The soil texture was determined by means of sieving the sand fraction from the silt and clay fraction (Van Reeuwijk, 2002). 
Table 2. The texture of soil material sampled from a depth of $0-25 \mathrm{~cm}$

\begin{tabular}{|c|c|c|c|c|}
\hline \multicolumn{4}{|c|}{ Percentage content of soil fractions \% } & \multirow[b]{2}{*}{ Texture class } \\
\hline \multirow{2}{*}{ Fraction } & $\begin{array}{c}\text { Sand } \\
2-0.05 \mathrm{~mm}\end{array}$ & $\begin{array}{c}\text { Silt } \\
0.05-0.002\end{array}$ & $\begin{array}{c}\text { Clay } \\
<0.002\end{array}$ & \\
\hline & 78 & 18 & 4 & LS \\
\hline
\end{tabular}

LS - loamy sand

The agrotechnical treatments were carried out as recommended for the specie tested. The following crop protection products were applied: herbicides: Stomp Aqua 455 CS $\left(2.6 \mathrm{~L} \mathrm{ha}^{-1}\right)$ in April and Pantera $040 \mathrm{EC}\left(1.75 \mathrm{~L} \mathrm{ha}^{-1}\right)$ in May; Piorun $200 \mathrm{SL}\left(0.2 \mathrm{~L} \mathrm{ha}^{-1}\right)$ in June or Fastac 100 EC $0.1\left(\mathrm{~L} \mathrm{ha}^{-1}\right)$ in August; fungicides: Korazzo 250 SC $1.0\left(\mathrm{~L} \mathrm{ha}^{-1}\right)$ in June.

\section{Weather conditions}

The weather course in the years of the study was presented as mean values of the Sielianinov (Stachowski, 2010) hydrothermal indicator (Fig. 2), calculated based on meteorological data registered in the Experimental Station. Interpretation of the indicator: $\mathrm{K}>1.5$ - excess moisture for plants, $\mathrm{K}=1.0-1.5$ - optimal humidity, $\mathrm{K}=0.5$ 1.0 - insufficient humidity for plants, $\mathrm{K}<0.5$ - humidity below required for plants (drought). During the growing seasons in 2016 and 2017 the weather conditions were similar in terms of temperature and rainfall. During the growing season the highest average air temperature was noted in July both in $2016\left(19.5^{\circ} \mathrm{C}\right)$ and $2017\left(18.9^{\circ} \mathrm{C}\right)$, whereas the lowest temperature was noted in April, i.e. $8.7^{\circ} \mathrm{C}$ in 2016 and $7.5^{\circ} \mathrm{C}$ in 2017. However, the weather conditions in 2018 were different than in the previous years (Fig. 1). The highest average temperature was noted in August $\left(21.2^{\circ} \mathrm{C}\right)$, whereas the lowest was noted in May $\left(12.7^{\circ} \mathrm{C}\right)$. As far as the average monthly temperature from April to September is concerned, 2018 was the warmest - it was $2.9{ }^{\circ} \mathrm{C}$ warmer than 2016 and $1.7^{\circ} \mathrm{C}$ warmer than 2017 . In 2016 there was drought only at the end of the growing season. Likewise, in 2017 there was no rainfall deficit. On the contrary, it was a wet year, especially from June to August. On the other hand, in 2018 rainfall was unevenly distributed and there were droughts which were particularly unfavourable for plants in May, June and August.

\section{Influence of fertilisers on nitrogenase activity (diazotrophy)}

Plants representing each experimental variant (5 on average) were selected to measure the diazotrophy level. The analyses were made at the beginning of the flowering period. The nitrogenase activity (diazotrophy) was tested with the acetylene method on a CHROM5 gas chromatograph (Sawicka, 1983). The amount of acetylene reduced to ethylene was measured and expressed as $\mathrm{nMC}_{2} \mathrm{H}_{4}$ plant $^{-1} \mathrm{~h}^{-1}$.

\section{Microbial analyses}

Soil samples collected from the arable layer $(0-20 \mathrm{~cm})$ were used as the research material for biochemical analyses. Each year they were collected at four terms: $1^{\text {st }}$ term - at the plants' emergence (BBCH 5-10), $2^{\text {nd }}$ term - at the plants' full growth (BBCH $35-40), 3^{\text {rd }}$ term - at the plants' florescence $(\mathrm{BBCH} 51-59), 4^{\text {th }}$ term - after harvest. 
Soil samples were taken from five places of each experimental plot, in four replications for each of the nine variants of the experiment. In this way, at each analysis term we received 36 samples of soil, each of $1 \mathrm{~kg}$.

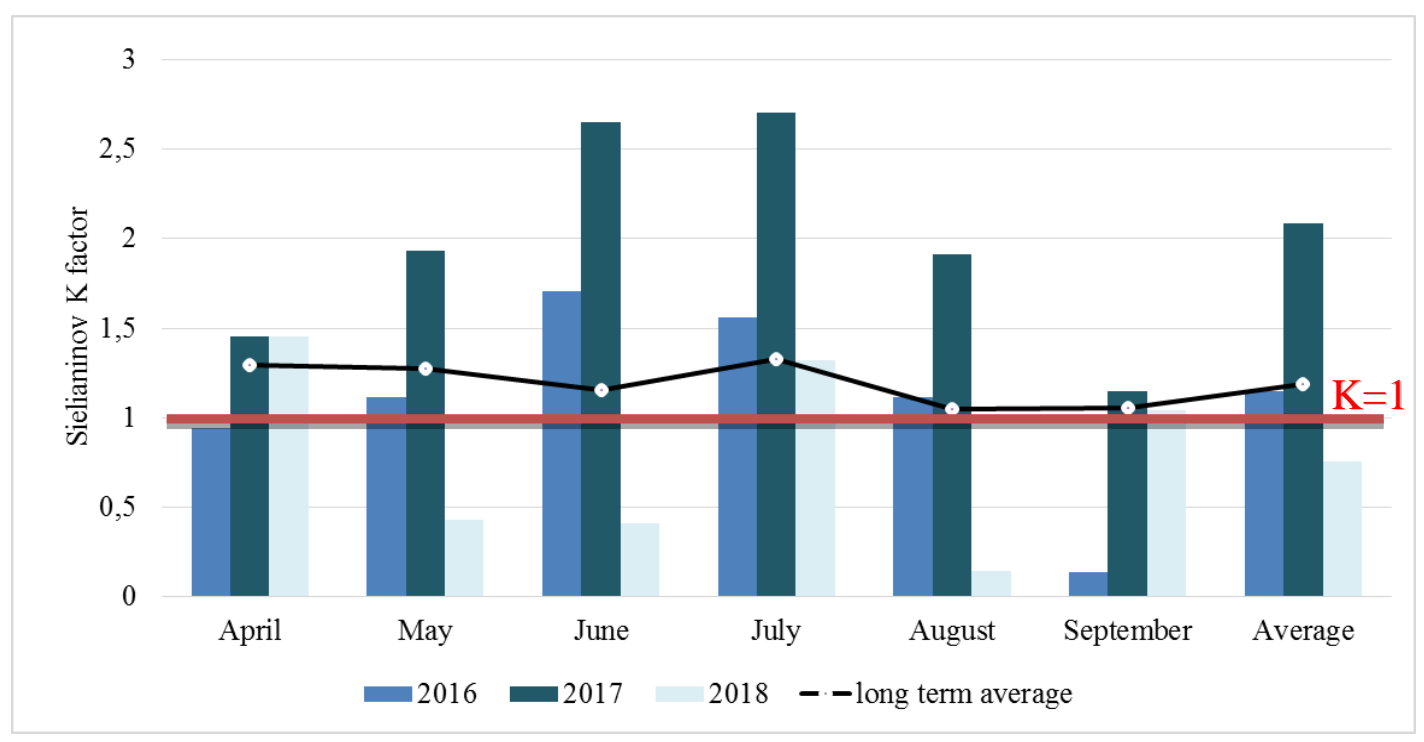

Figure 2. Climate graph according to Sielianinov characterizing weather conditions in Gorzyń

\section{Soil enzymatic activity}

The analyses of soil enzymatic activity in individual variants were based on the colorimetric method applied to measure dehydrogenase activity (DHA), where $1 \%$ triphenyl tetrazolium chloride (TTC) was used as the substrate. The activity was measured after 24-h incubation at a temperature of $30^{\circ} \mathrm{C}$ and a wavelength of $485 \mathrm{~nm}$ and it was expressed as $\mu$ mol triphenyl formazane (TPF) $24 \mathrm{~h}^{-1} \mathrm{~g}^{-1} \mathrm{dm}$ of soil (Thalmann, 1968).

Additionally, acid phosphomonoesterase activity was measured (EC 3.1.3.2) (PAC) by means of the method developed by Tabatabai and Bremner (1969), where disodium p-nitrophenyl phosphate tetrahydrate was the substrate. The activity was measured after 1-h incubation at $37{ }^{\circ} \mathrm{C}$ and a wavelength of $400 \mathrm{~nm}$. The results were converted into $\mu \mathrm{mol}$ (p-nitrophenol) $\mathrm{PNP} \mathrm{h}^{-1} \mathrm{~g}^{-1} \mathrm{dm}$ of soil.

Catalase activity was measured by means of permanganometry, according to the method developed by Johnsons and Temple (1964), where $0.3 \% \mathrm{H}_{2} \mathrm{O}_{2}$ was the substrate. After 20-min incubation at room temperature (about $20{ }^{\circ} \mathrm{C}$ ) $0.02 \mathrm{M} \mathrm{KMnO}_{4}$ was titrated to a light pink colour and expressed as $\mu \mathrm{mol} \mathrm{H}_{2} \mathrm{O}_{2} \mathrm{~g}^{-1} \mathrm{~d}$.m. min $^{-1}$.

\section{Biological index of fertility}

The biological index of fertility (BIF) was calculated using the dehydrogenase activity (DHA) and catalase activity (CAT) in the following formula: (DHA + kCAT)/2, where $\mathrm{k}$ was the factor of proportionality and equalled 0.01 (Saviozzi et al., 2004).

\section{Statistical analyses}

The dynamics of changes in the soil enzymatic activity were analysed statistically. The results were analysed with two-way ANOVA using Statistica 9.1 software. The 


$$
-12655 \text { - }
$$

fertilisation method and the term of analysis were the factors differentiating the traits under study. The significance of differences between the pairs of factors was checked with Tukey's test. Principal component analysis (PCA) was used to visualise the multidimensional dependencies between the soil biochemical activity and the types of fertilisation.

\section{Results}

The experiment showed the influence of biostimulants and foliar fertilisers on soil enzymatic activity and fertility (BIF) as well as nitrogenase activity under a soybean plantation. The two-way analysis of variance revealed the highly significant effect $(\mathrm{p}=0.001)$ of foliar fertilisation/biostimulants and the term of tests on enzymatic activity and the biological index of fertility (BIF) of soil under the soybean plantation (Table 3).

Table 3. F-test statistics and significance levels of two-way analysis of variance for soil bioactivity. Foliar fertilisation/biostimulants and the terms of tests were the factors influencing the traits under study

\begin{tabular}{c|c|c|c}
\hline Parameter & Treatment & Term & Interaction \\
\hline Dehydrogenase & $5.84^{* * * *}$ & $131.512^{* * * *}$ & $5.63^{* * * *}$ \\
Alkaline phosphatase & $14.94^{* * *}$ & $146.6^{* * * *}$ & $4.62^{* * *}$ \\
Acid phosphatase & $7.61^{* * *}$ & $137.40^{* * * *}$ & $6.765^{* * *}$ \\
Catalase & $16.9^{* * *}$ & $142.82^{* * *}$ & $16.66^{* * *}$ \\
BIF & $14.06^{* * *}$ & $192.4^{* * *}$ & $14.065^{* * *}$ \\
Nitrogenase & $7.08^{* * *}$ & - & - \\
\hline
\end{tabular}

$\mathrm{F}$ test statistics and significance levels of two-way analysis of variance for activity of enzymes associated with herbicides and terms research fixed factors. ${ }^{* * *} \mathrm{p}=0.001$

\section{Biological fixation of nitrogen under soybean plantation}

The field analyses of biological nitrogen fixation showed that the fertilisers and biostimulants significantly stimulated nitrogenase activity under the soybean plantation. The diagram (Fig. 3) presents the average nitrogenase activity during the three years of the study. In comparison with the control sample, nitrogenase activity increased in all the experimental variants. The application of the Tytanit and Rooter biostimulants resulted in the highest nitrogenase activity. In comparison with the control plot, nitrogenase activity in these variants increased by $77 \%$ and $69 \%$, respectively. Apart from the control sample, the lowest biological nitrogen fixation activity was observed in the Bolero Mo variant.

\section{Analysis of soil biochemical activity}

Figure 4 shows the results of the analysis of dehydrogenase activity in the soil under the soybean plantation. During the three years of the experiment the foliar fertilisers and biostimulants significantly stimulated the catalytic dehydrogenase activity in all the experimental variants, as compared with the control variant. The ADOB 2.0 Mo and Bolero Mo foliar fertilisers resulted in the highest dehydrogenase activity. The research 
also showed that the highest dehydrogenase activity occurred at the second term of analyses, when the plants were at the phase of full growth (BBCH 35-40).

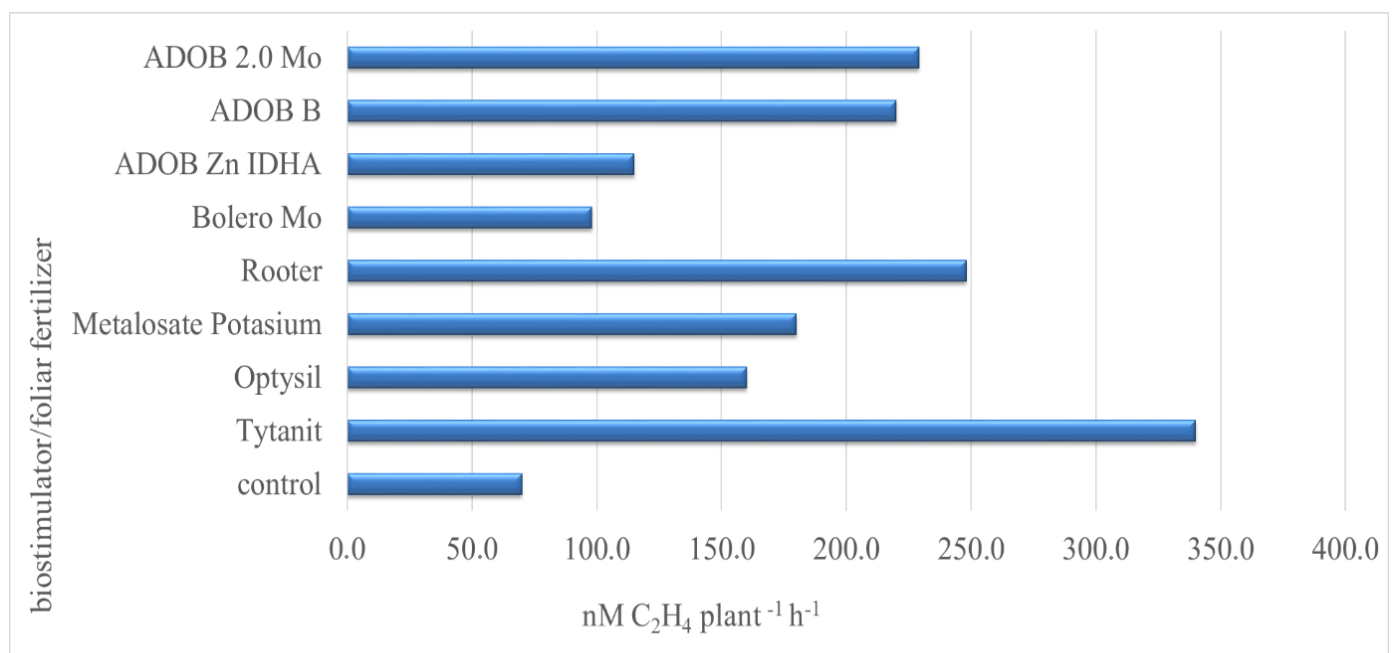

Figure 3. The influence of the biostimulants and fertilisers on biological nitrogen fixation

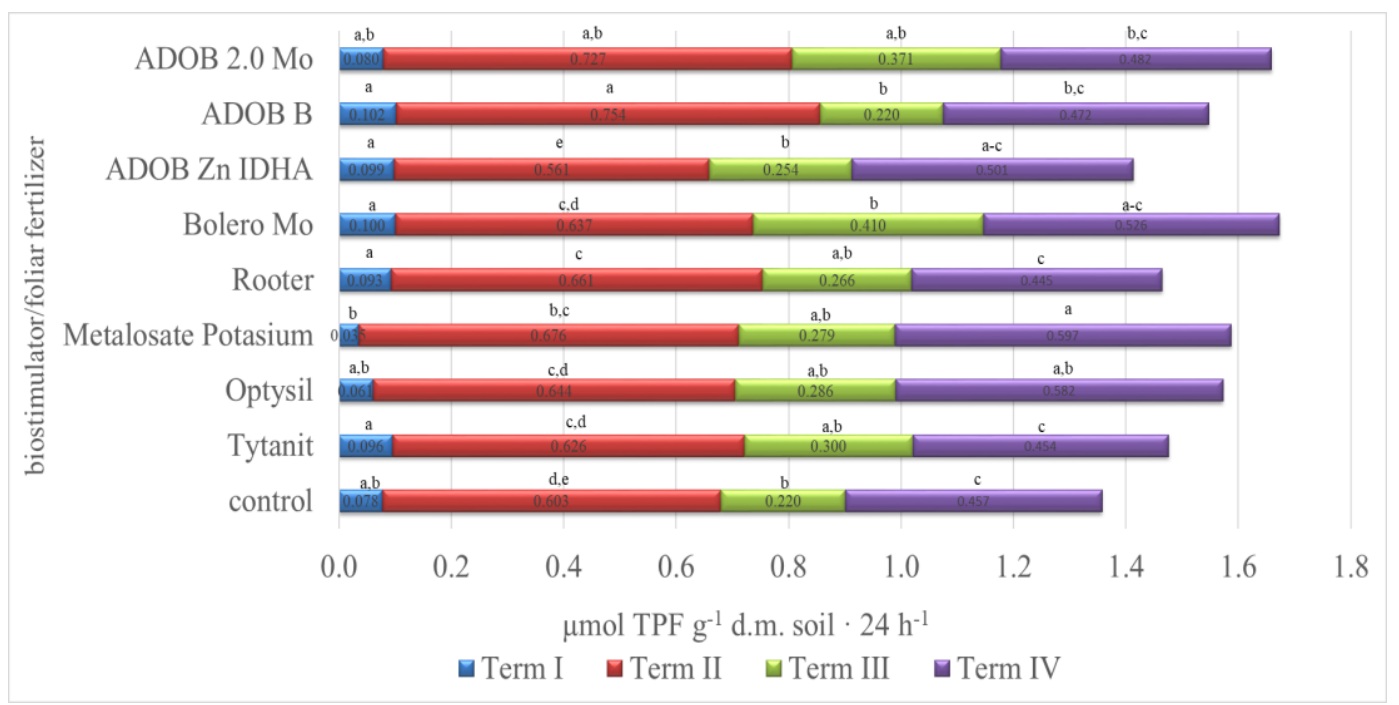

Figure 4. The influence of biostimulants and fertilisers on dehydrogenase activity. (Note: data are represented as means of five replications. $a, b, c, d, e-$ homogenous groups according to Tuckey's test; different letters denote statistical differences at level $\alpha=0.05 ; n=5$, in the same term)

The analysis of the results of acid phosphatase activity (PAC) during the entire soybean growing period showed that in comparison with the control variant it decreased significantly when Tytanit and Rooter biostimulants and Bolero Mo foliar fertiliser were applied (Fig. 5). This effect was not observed with the other foliar fertilisers, i.e. Optysil, Metalosate Potassium, ADOB Zn IDHA, ADOB B and ADOB 2.0 Mo. Moreover, at the second term of analyses, i.e. at the stage of full development of the plant just before flowering, acid phosphatase activity in all the experimental variants 


$$
-12657 \text { - }
$$

was higher than in the control variant. The highest activity was observed after the application of ADOBE 2.0 Mo and Optysil foliar fertilisers (Fig. 5).

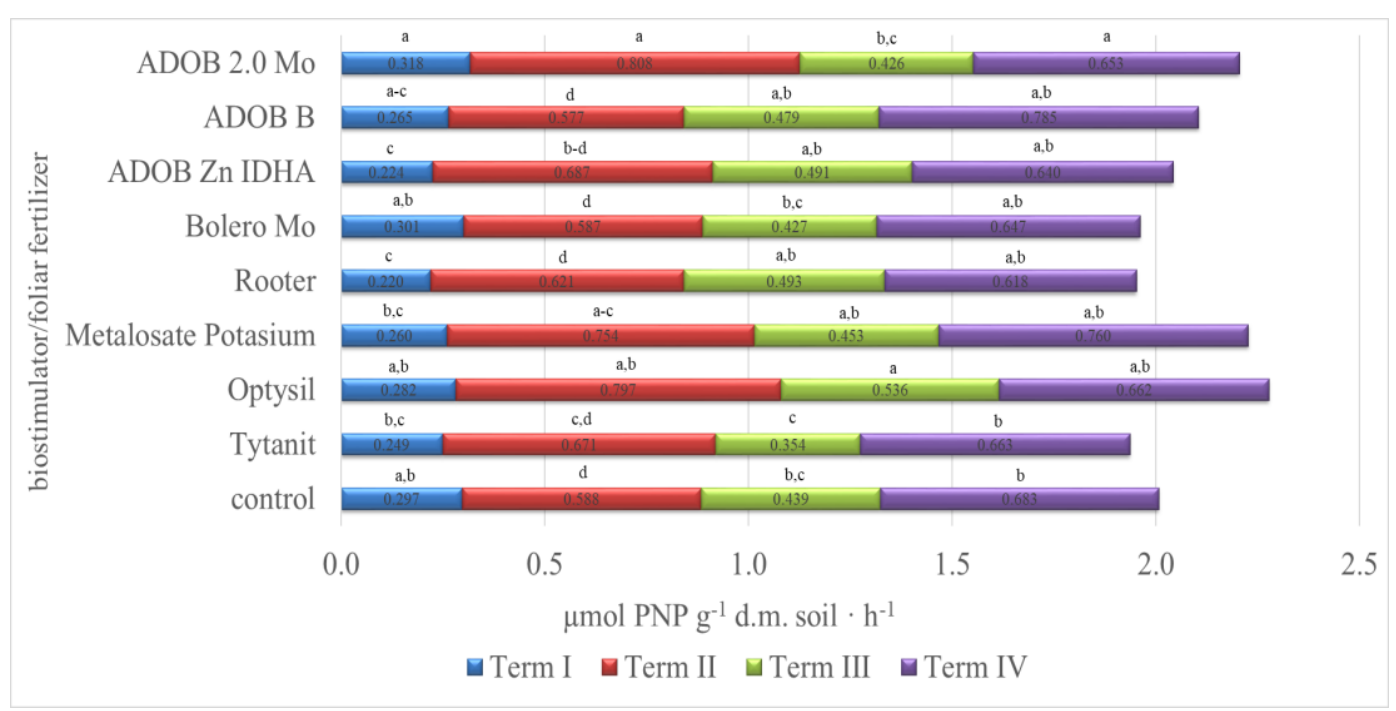

Figure 5. The influence of the biostimulants and fertilisers on acid phosphatase activity. (Note: data are represented as means of five replications. $a, b, c, d, e$-homogenous groups according to Tuckey's test; different letters denote statistical differences at level $\alpha=0.05 ; n=5$, in the same term)

The analysis showed that in comparison with the control variant the biostimulants and most of the foliar fertilisers used in the research increased alkaline phosphatase activity (PAL) (Fig. 6). Metalosate Potassium and Bolero Mo foliar fertilisers stimulated enzyme activity particularly significantly. In comparison with the control variant, the Tytanit and Rooter biostimulants increased PAL activity by $6 \%$ and $5 \%$, respectively. Similarly to dehydrogenase activity, alkaline phosphatase activity also increased significantly at the second term of analyses after the application of the fertilisers and biostimulants.

The analysis of catalase activity revealed that apart from Tytanit, all the preparations significantly stimulated this enzyme, as compared with the control variant (Fig. 7). The application of the Metalosate Potassium resulted in the highest catalase activity. The research also showed that the enzyme exhibited high activity at the fourth term of analyses, i.e. after the harvest in all experimental variants, where it ranged from $55.9 \mu \mathrm{mol} \mathrm{H}_{2} \mathrm{O}_{2} \mathrm{~g}^{-1}$ d.m. min $^{-1}$ after treatment with Tytanit biostimulant to $149.7 \mu \mathrm{mol}$ $\mathrm{H}_{2} \mathrm{O}_{2} \mathrm{~g}^{-1}$ d.m. min $^{-1}$ after the application of Metalosate Potassium.

The biological index of soil fertility (BIF) calculated on the basis of the dehydrogenase and catalase activity was significantly greater after treatment with all the biostimulants and foliar fertilisers (Fig. 8). The highest value of the index was noted when Metalosate Potassium foliar fertiliser was applied to the soybean plantation. By contrast, ADOB 2.0 Mo foliar fertiliser resulted in the lowest BIF value. The BIF also had a very high value at the phase of the plants' florescence. It ranged from 2.77 after treatment with ADOB 2.0 Mo fertiliser to 8.34 after the application of Bolero Mo fertiliser. Treatment with ADOB Zn IDHA and ADOB B fertilisers also resulted in high BIF values. 


\section{- 12658 -}

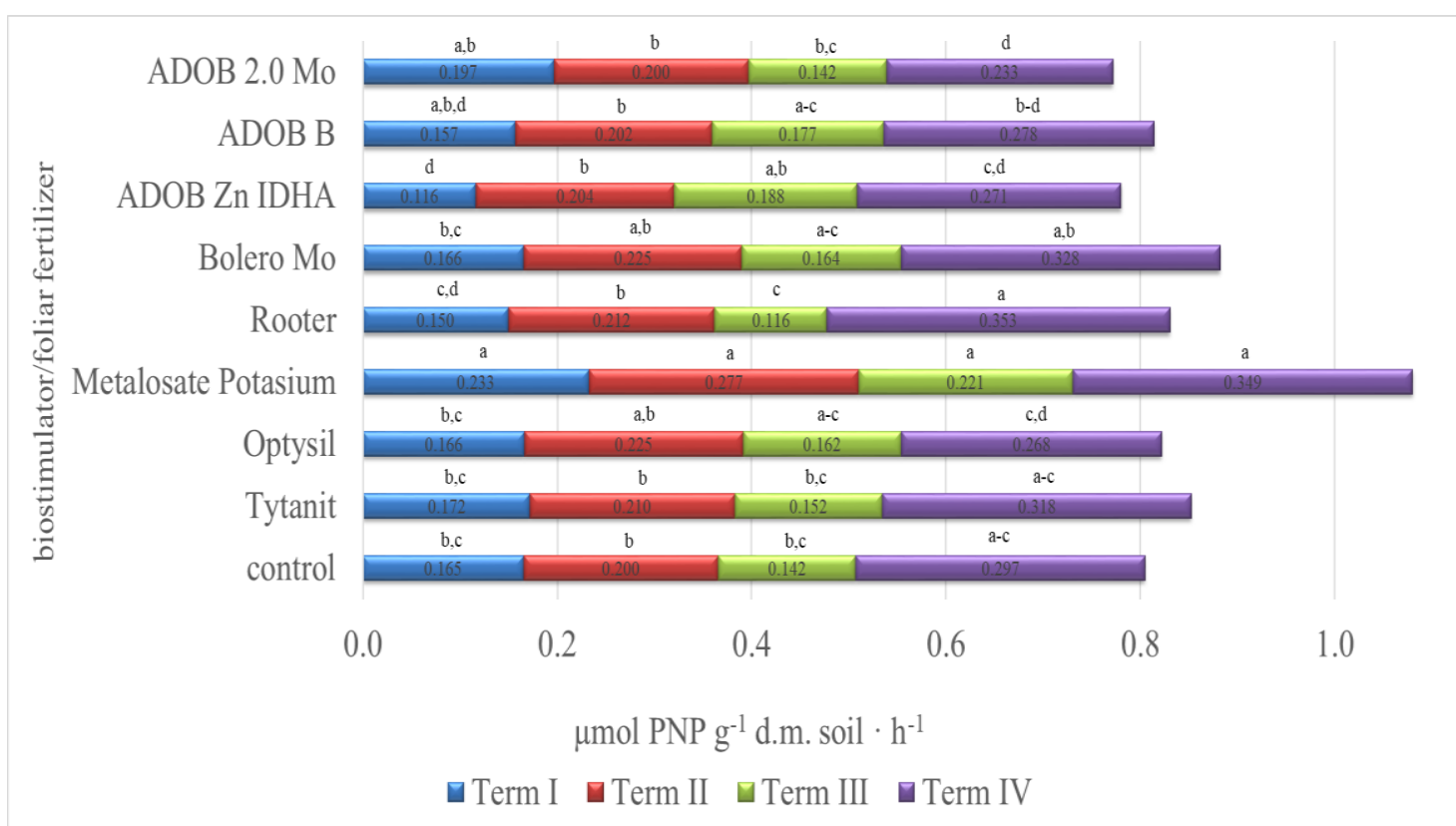

Figure 6. The influence of the biostimulants and fertilisers on alkaline phosphatase activity. (Note: data are represented as means of five replications. $a, b, c, d, e$-homogenous groups according to Tuckey's test; different letters denote statistical differences at level $\alpha=0.05$;

\section{$n=5$, in the same term)}

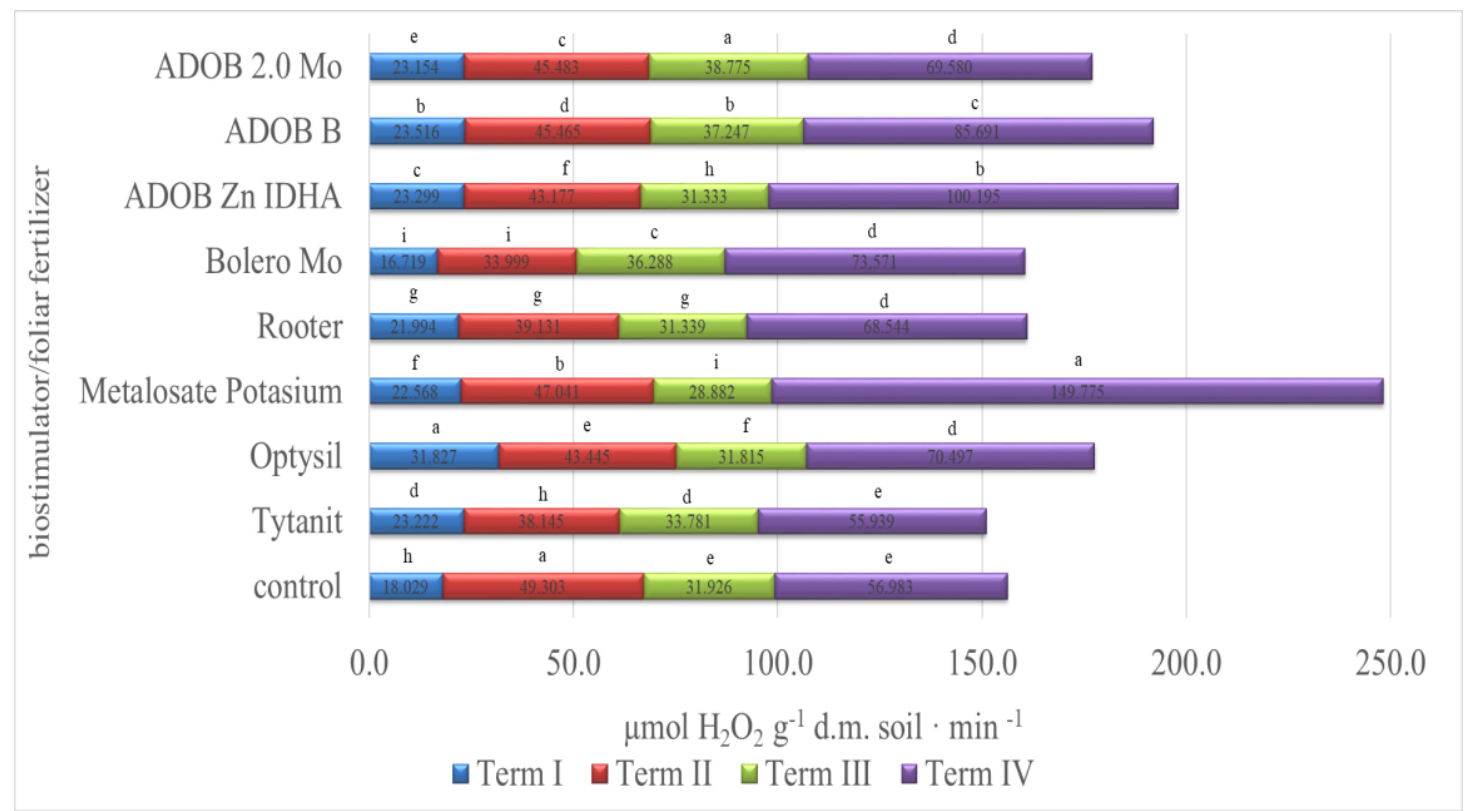

Figure 7. The influence of the biostimulants and fertilisers on catalase activity. (Note: data are represented as means of five replications. $a, b, c, d, e, f, g, h$-homogenous groups according to Tuckey's test; different letters denote statistical differences at level $\alpha=0.05 ; n=5$, in the same term) 


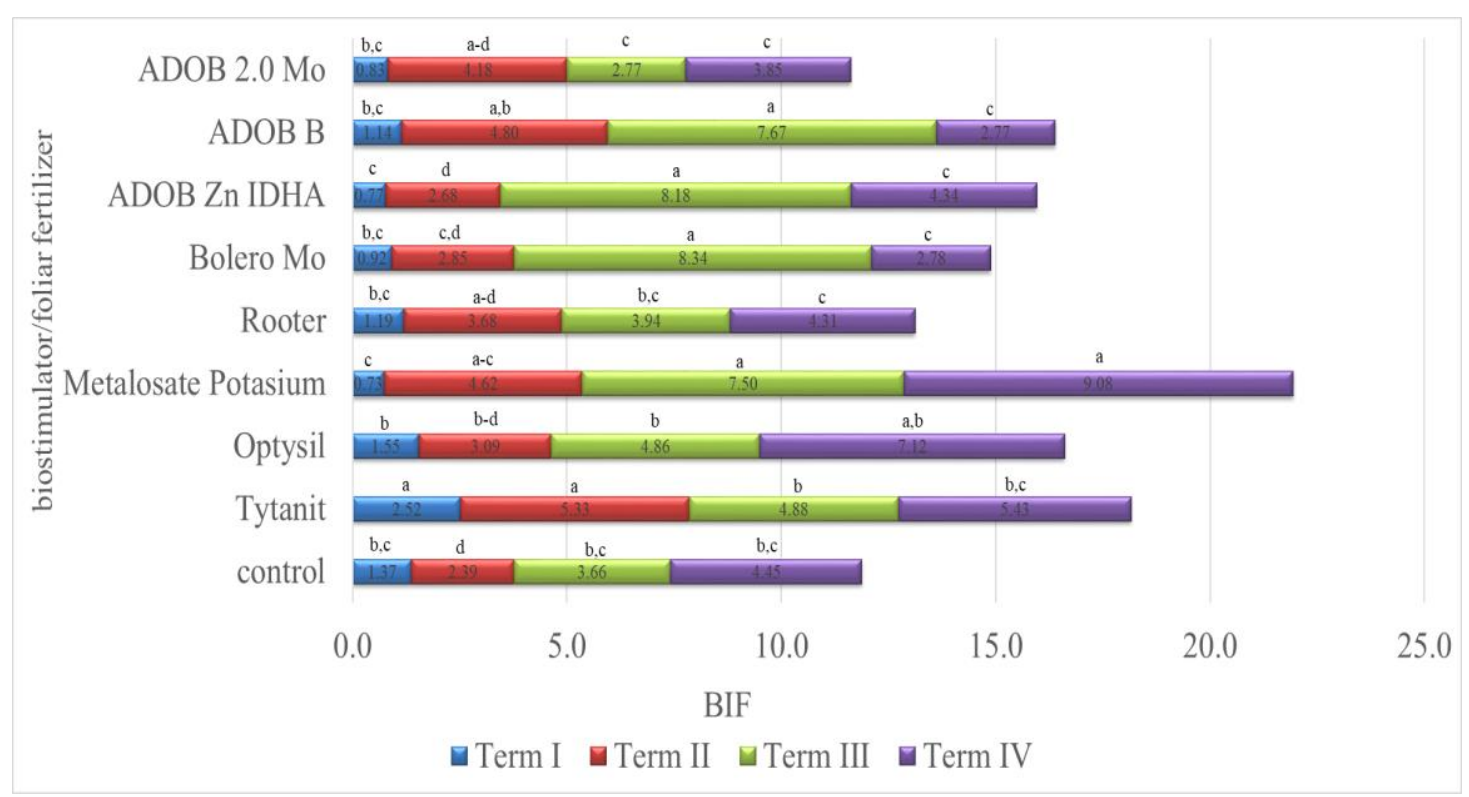

Figure 8. The influence of the biostimulants and fertilisers on the BIF value. (Note: data are represented as means of five replications. $a, b, c, d$-homogenous groups according to Tuckey's test; different letters denote statistical differences at level $\alpha=0.05 ; n=5$, in the same term)

The influence of the foliar fertilisers and biostimulants applied to the soybean plantation at specific terms was subjected to principal component analysis (PCA) (Fig. 9). The first two main components explained more than $77.68 \%$ of the total variance. The parameters of soil biochemical activity in 2018 were considerably divergent from those observed in 2016 and 2017, probably as a result of the weather conditions (Fig. 1). The growing season in 2018 was the warmest of all the research years. In comparison with the previous years, the average temperature difference amounted to $2.9{ }^{\circ} \mathrm{C}$ in August and $1.7{ }^{\circ} \mathrm{C}$ in May. In 2016 and 2017 the thermal conditions were very similar so the PCA showed similar dependencies for those two years. In those years, at the phase of the plants' florescence (the $3^{\text {rd }}$ term of analyses) and after the harvest (the $4^{\text {th }}$ term of analyses), the biostimulants and foliar fertilisers significantly influenced alkaline phosphatase activity and the value of the biological index of fertility (BIF). In 2018, the $2^{\text {nd }}$ and $4^{\text {th }}$ terms of analyses influenced the catalytic activity of catalase (CAT) and dehydrogenase (DHA).

\section{Discussion}

\section{Biological nitrogen fixation}

The biostimulants and foliar fertilisers which increased the biological fixation of nitrogen under the soybean plantation contained the essential macro- or microelements for this process. According to scientific reports, the role of some chemical elements in the process of nitrogen fixation is very important.

Molybdenum, boron, iron, and cobalt are among the micronutrients that significantly affect plants' development and the nitrogen fixation process. Molybdenum and iron are particularly important elements. They are components of nitrogenase - the bacterial enzyme thanks to which the diazotrophy process is possible. Nitrogenase is a protein 
composed of two subunits - the larger one containing the FeMo cofactor and the smaller one containing iron only (Symanowicz et al., 2005). The availability of molybdenum is naturally limited in acidic, moist, and poorly buffered soils. According to some reports, when the leaves of leguminous plants are treated with molybdenum in a field, the nitrogen fixation efficiency, the weight of root nodules, and the seed yield increase (Vieira, 1998; Weisany et al., 2013). This effect was also observed in our research when the ADOB 2.0 Mo fertiliser with high molybdenum content was applied. Although plants contain small amounts of boron, this microelement plays an important role in a wide range of physiological processes. It affects the separation of plant tissues and is necessary for the optimal growth of plants. Plants with boron deficit have fewer Rhizobium cells and infectious threads (Brown et al., 2002; Weisany et al., 2013). The significantly higher rate of biological nitrogen fixation after the application of the foliar fertiliser with boron (ADOB B - variant 8) could have caused the increase in the content of this parameter.

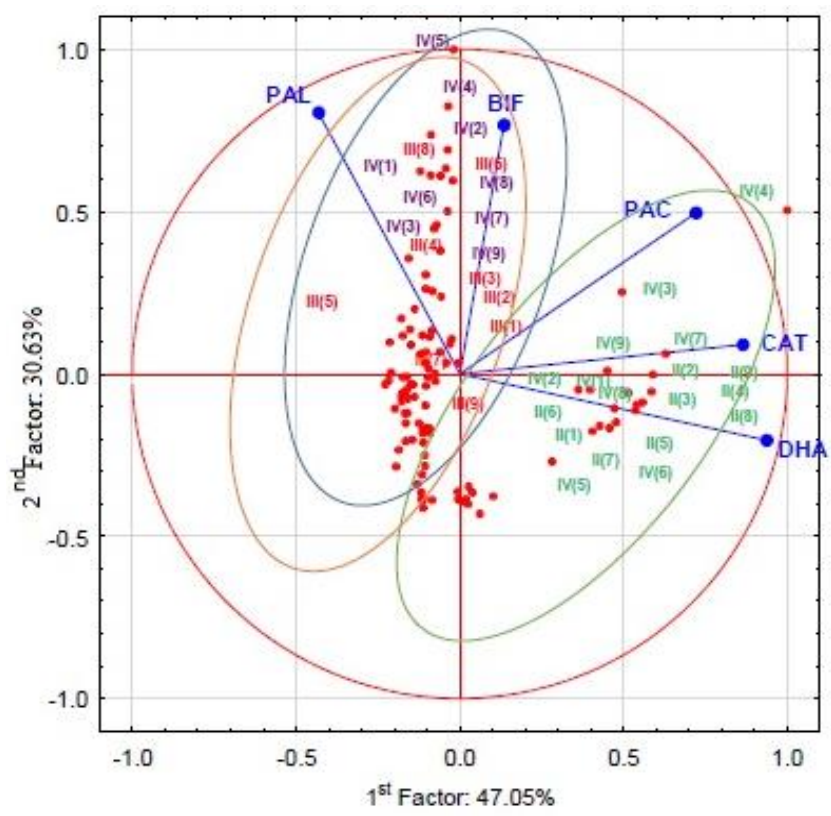

Figure 9. The dependence between soil enzymatic activity for all variants with fertilisers and biostimulants at the terms of analyses; $I-I^{\text {st }}$ term, II - $2^{\text {nd }}$ term, III - $3^{\text {rd }}$ term, IV $-4^{\text {th }}$ term; (1) control sample - no biostimulants or foliar fertilisers; (2) Tytanit; (3) Optysil; (4) Metalosate Potassium (potassium + amino acids); (5) Rooter; (6) Bolero Mo - liquid suspension boron fertiliser with molybdenum; (7) ADOB Zn IDHA (chelated zinc); (8) ADOB B (high boron content); (9) ADOB 2.0 Mo (high molybdenum content); PAC - acid phosphatase; $P A L$ alkaline phosphatase; DHA - dehydrogenase; BIF - biological index of fertility

The role of phosphorus in symbiotic systems has also been the subject of many studies which have confirmed its key importance for the efficiency of atmospheric nitrogen fixation (Bucher, 2007; Bonilla and Bolaños, 2009). The Rooter biostimulant, which contained phosphorus and potassium, had a highly stimulating effect on the nitrogen fixation process. Phosphorus participates in a wide range of molecular and biochemical processes, and some phosphate bonds carry the energy used in cells. The presence of phosphorus in soil affects plants' ability to form root nodules, especially the 
weight and number of nodules (Abusuwar and Omer, 2011), which translates to the nitrogen fixation level.

When plants are deficient in phosphorus they are usually deficient in nitrogen too. The role of sulphur and potassium is less important for symbiotic systems than that of the abovementioned elements. Nevertheless, potassium ions are very desirable in saline soils because they function as osmolytes. In view of the fact that almost half of the irrigated soils around the world are considered to be saline, the addition of potassium helps to maintain the symbiotic system between bacteria and plants (Zahran, 1999; Bonilla and Bolaños, 2009).

\section{Biochemical activity}

Soil enzymes are a group of catalysts that play a permanent and major role in maintaining the ecological properties of the pedosphere, its physicochemical properties, fertility and health (Das and Varma, 2011; Utobo and Tewari, 2015; Niewiadomska et al., 2018b). These include both extracellular enzymes and those that can be found in microorganisms (both in proliferating cells and in sporulating forms). Enzymes are responsible for the course of all chemical reactions in microbial cells, including the synthesis of proteins, nucleic acids or carbohydrates (Błońska, 2011). On the other hand, soil enzymes participate in the decomposition of organic matter released into the soil during plants' growth, the formation and decomposition of humus as well as the release and transfer of mineral substances to plants. Although microbiological and biochemical properties are dynamic, enzymes are a precise and important determinant of soil fertility and they are of even greater significance when it is necessary to determine changes occurring in soil (Burns et al., 2013; Niewiadomska et al., 2018a).

When fertilisers are applied into soil, the enzymatic activity changes significantly. The direction and intensity of the change depends on the type and dose of fertiliser and on the enzyme in question (Selivanovskaya et al., 2006; Napora and Grobelak, 2014). Changes in the activity of soil enzymes reflect environmental disturbances, which influence both the soil and plants (Bielińska and Mocek-Płóciniak, 2012).

Dehydrogenases (DHA) are enzymes belonging to the group of oxidoreductases. They catalyse the oxidation of organic compounds. Active dehydrogenases can only be found inside living cells and their presence indicates the presence of physiologically active microorganisms. They are commonly found in the pedosphere, where they participate in the decomposition of organic compounds. The identification of dehydrogenase activity in soil indicates the intensity of the respiratory metabolism of soil microorganisms, mostly actinobacteria and eubacteria.

The study showed that the biostimulants and foliar fertilisers significantly stimulated dehydrogenase activity. The activity was high during the period of full growth of soybeans, i.e. at $\mathrm{BBCH} 30-45$. It may have been caused by increased secretions from the root system at the time and it resulted in a greater count of microorganisms. Dehydrogenase activity also increased considerably after the harvest, which may have been caused by the fact that organic matter in the form of crop residue entered the soil. Kang et al. (2009) also observed a similar increase in dehydrogenase activity in the spring and autumn. In our study the activity of this enzyme in the spring may also have been stimulated by higher rainfall in June. Brzezińska et al. (2001) and Błońska et al. (2012) reached similar conclusions in their studies, where they proved that the high humidity of the substrate increased dehydrogenase activity. The macro- and microelements applied with the foliar fertilisers and biostimulants were also significant. 
Bielińska et al. (2013) noticed that fertilisers containing nitrogen, phosphorus and potassium had a positive influence on the dehydrogenase content in the soil. Swędrzyńska et al. (2013) and Niewiadomska et al. (2018a) made similar observations in their studies on similar biological soil conditioners. According to Bilen et al. (2011) and Kumar et al. (2015), boron increases dehydrogenase activity. Taran et al. (2014) proved that molybdenum stimulated the production of these enzymes by the root nodules of leguminous plants and discussed a possible positive correlation between titanium and soil biochemistry.

The biostimulants used in the experiment (Tytanit and Rooter) had a positive effect on acid phosphatase activity because they reduced its level. Apart from the Bolero Mo, the other foliar fertilisers used in the experiment did not cause this effect. This shows that these biostimulants and the foliar fertiliser positively affected the plants' ability to absorb phosphorus. The acid phosphatase activity in the other experimental variants was higher than in the control variant. It is important to remember that when plants are exposed to phosphorus deficiency they increase the secretion of acid phosphatase through the root system into the soil. These dependencies were confirmed in the studies by Lemanowicz and Koper (2012) and Niewiadomska (2013), who investigated the effect of PRP SOL fertiliser containing phosphorus, potassium, zinc, boron and molybdenum under an alfalfa plantation. The research showed that the fertiliser decreased the catalytic activity of acid phosphatase by activating inaccessible compounds for plants. Bielińska and Mocek-Płóciniak (2009) made similar observations. Lemanowicz and Koper (2010) also observed higher activity of these enzymes in the experimental variant which was not fertilised with phosphorus. Rotaru (2015) found that the deficit of this macroelement stimulated plants' secretion of acid phosphatases.

As far as alkaline phosphatase is concerned, most of the foliar fertilisers significantly increased the activity of this enzyme. It may have been stimulated by increased activity of the soil microorganisms reacting to organic phosphorus compounds released by soybean plants into the soil. Lemanowicz and Koper (2010) proved the correlation between the content of organic forms of phosphorus and the activity of alkaline phosphatases in soil.

With the exception of Tytanit, the other preparations applied in the experiment significantly stimulated catalase activity. As early as 1963, Koter demonstrated higher catalase activity in plants fertilised with boron. Hu and Zhu (2008) observed that fertilisation with silicon increased the activity of catalase and dehydrogenases. Romanowicz and Krzepiłko (2013) indicated that soil oxygenation and temperature significantly affected catalase activity. According to Szymczak et al. (2011), the catalytic activity of this enzyme is a good marker of physiological stresses in plants.

The results of analyses of the catalase and dehydrogenase activity enabled the calculation of the biological index of soil fertility (BIF). The variants with Metalosate potassium and Tytanit preparations had a significant influence on the BIF values, as compared with the control sample. The former preparation resulted in particularly high BIF values in the soil samples collected after the harvest of soybean plants. This effect was caused by the significant influence of these fertilisers on the activity of catalase and dehydrogenases. According to Natywa et al. (2014), mineral fertilisation, which increases the yield of crops, indirectly affects the amount of crop residue and thus increases the biochemical activity of soil after harvest. 


\section{Conclusion}

When foliar fertilisation is applied, the plant extracts the necessary elements mostly through the leaves, but also through the stem and the entire aerial system. However, it is necessary to remember that this method of 'feeding' cannot replace soil fertilisation. It only quickly provides the necessary ingredients to the plant at difficult phases so as not to slow down its growth. The biostimulants and foliar fertilisers applied in our research stimulated most of the parameters of soil biochemical activity and the process of nitrogen fixation under the soybean plantation. This may have been caused by the fact that the foliar application of nutrients to the plants increased the rate of their penetration and resulted in higher efficiency of their use. Macro- and micronutrients differ in their rate of penetration but foliar fertilisation accelerates this process several times. The disadvantage of foliar fertilisation is the limited amount of the fertiliser that can be provided to plants. Therefore, this method is particularly effective when it is necessary to supply them with the elements that they need in smaller amounts, e.g. iron, boron, and molybdenum. Apart from the increased efficiency of the foliar application of micronutrients, this method is also safer for the environment and for the plant itself. The search for methods that increase the yield and biochemical parameters of the soil environment is an important part of sustainable agriculture policy.

We can observe increasing importance of legumes in sustainable agriculture. The following facts speak in favour of cultivation of this group of plants: they improve the physicochemical properties of soil, enrich the content of organic matter and leave large amounts of crop residues with high content of nitrogen. Soybean (Glycine max L.) is one of the most important crops in this group of plants. Soybean seeds contain about $40 \%$ of protein with a favourable amino acid composition and $20 \%$ of fat, with the majority of unsaturated fatty acids. Conducting further research in the search for preparations supporting the yielding capacity of soybeans, while not affecting the environment, seems necessary in the realities of modern agriculture.

Acknowledgements. This research was financed by the Ministry of Agriculture and Rural Development of the Republic of Poland in the framework of the Multi-annual Program 'Increasing the use of domestic feed protein for the production of high quality animal products in conditions of balanced development' implemented at the Department of Agronomy of the University of Life Sciences in Poznan.

\section{REFERENCES}

[1] Abusuwar, A. O., Omer, E. A. (2011): Effect of intercropping, phosphorus fertilization and rhizobium inoculation on the growth and nodulation of some leguminous and cereal forages. - Agriculture and Biological Journal of North America 2: 109-124.

[2] Bielińska, E., Mocek-Płóciniak, A. (2009): Phosphatases in the Soil Environment. - UP Pub., Poznan.

[3] Bielińska, E., Mocek-Płóciniak, A. (2012): Impact of the tillage system on the soil enzymatic activity. - Archives of Environmental Protection 38(1): 75-82.

[4] Bielińska, E. J., Futa, B., Bik-Mołodzińska, M., Szewczuk, C., Sugier, D. (2013): The impact of fertilizing agents on the enzymatic activity of soils. - Journal of Research and Applications in Agricultural Engineering 58(3): 15-19 (in Polish).

[5] Bilen, S., Bilen, M., Bardhan, S. (2011): The effects of boron management on soil microbial population and enzyme activities. - African Journal of Biotechnology 10(27): 5311-5319. 
[6] Błońska, E. (2011): Soil enzymes and their importance in assessing the biological activity of forest soils on the example of nature reserves in the Polish lowlands and uplands. Soil Science Annual 62(4): 163-172.

[7] Błońska, E., Lasota, J., Januszek, K. (2012): Enzyme activity in forest gleysols. - Soil Science Annual 63(4): 3-8 (in Polish).

[8] Bonilla, I., Bolaños, L. (2009): Mineral nutrition for legume-rhizobia symbiosis: B, Ca, $\mathrm{N}, \mathrm{P}, \mathrm{S}, \mathrm{K}, \mathrm{Fe}, \mathrm{Mo}, \mathrm{Co}$, and Ni. A review. - Organic Farming, Pest Control and Remediation of Soil Pollutants 1: 253-274.

[9] Borowska, M., Kaszkowiak, E., Prusiński, J. (2016): Production and economic effects of enhanced cultivation technology in white lupin (Lupines albus L.). - Problematic Notebooks about the Progress of Agricultural Sciences 585: 97-107.

[10] Brown, P. H., Bellaloui, N., Wimmer, M. A., Bassi, E. S., Ruiz, J., Hu, H., Pfeffer, H., Dannel, F., Römheld, V. (2002): Boron in plant biology. - Plant Biology 4: 205-223.

[11] Brzezińska, M., Stępniewska, Z., Stępniewski, W., Włodarczyk, T., Przywara, G., Bennicelli, R. (2001): Effect of oxygen deficiency on soil dehydrogenase activity (pot experiment with barley). - International Agrophysics 15: 3-7.

[12] Bucher, M. (2007): Functional biology of plant phosphate uptake at root and mycorrhiza interfaces. - New Phytollogist 173(1): 11-26.

[13] Burns, R. G., DeForest, J. L., Marxsen, J., Sinsabaugh, R. L., Stromberger, M. E., Wallenstein, M. D., Weintraub, M. N., Zoppini, A. (2013): Soil enzymes in a changing environment: current knowledge and future directions. - Soil Biology and Biochemistry 58: 216-234.

[14] Calvo, P., Nelson, L., Kloepper, J. W. (2014): Agricultural uses of plant biostimulants. Plant and Soil 383: 3-41.

[15] Das, S. K., Varma, A. (2011): Role of Enzymes in Maintaining Soil Health. - In: Shukla, G., Varma, A. (eds.) Soil Enzymology, Soil Biology 22. Springer-Verlag, Berlin.

[16] Directive 2009/128/EC of the European Parliament and of the Council of 21 October 2009 Establishing a Framework for Community Action to Achieve the Sustainable Use of Pesticides.

[17] Florek, J., Czerwińska-Kayzer, D., Jerzak, M. A. (2012): The current status and use of legume crops. - Fragmenta Agronomica 29(4): 45-55 (in Polish).

[18] Gawel, E. (2011): The role of small-seed leguminous plants on a farm. - WaterEnvironment-Rural Areas 11: 73-91 (in Polish).

[19] Giannattasio, M., Vendramin, E., Fornasier, F., Alberghini, S., Zanardo, M., Stellin, F., Concheri, G., Stevanato, P., Ertani, A., Nardi, S., Rizzi, V., Piffanelli, P., Spaccini, R., Mazzei, P., Piccolo, A., Squartini, A. (2013): Microbiological features and bioactivity of a fermented manure product (Preparation 500) used in biodynamic agriculture. - Journal of Microbiology and Biotechnology 23: 644-651.

[20] Hu, X. J., Zhu, Z. J. (2008): Effect of silicon on resistance of powdery mildew and the activities of antioxidative enzymes in leaf apoplast of cucumber. - Acta Agriculturae Zhejiangensis 20(1): 67-71.

[21] IUSS Working Group WRB (2007): World Reference Base for Soil Resources 2006. First Update 2007. - World Soil Resources Reports No.103. FAO, Rome.

[22] Johnson, J. L., Temple, K. L. (1964): Some variables affecting the measurement of "catalase activity" in soil 1. - Soil Science Society of America Journal 28(2): 207-209.

[23] Kang, H., Kang, S., Lee, D. (2009): Variations of soil enzyme activities in a temperate forest soil. - Ecological Research 24(5): 1137-1143.

[24] Karaca, A., Cetin, S. C., Turgay, O. C., Kizilkaya, R. (2010): Soil enzymes as indication of soil quality. - Soil Enzymology 22: 119-148.

[25] Koter, M. (1963): Research on the impact of boron on the growth and development of plants. - Soil Science Annual 13(1): 185-211. 


$$
-12665 \text { - }
$$

[26] Kumar, N., Misra, R., Shankhdhar, S. C., Shankdhar, D. (2015): Effect of foliar application of boron on growth, yiels, chlorophyll, amylose and nitrate reductase activity in rice. - ORYZA - An International Journal on Rice 52(2): 123-130.

[27] Lemanowicz, J., Koper, J. (2010): Changes in the content of available phosphorus and soil phosphatase activity as a result of fertilization. - Soil Science Annual 61(4): 140-145 (in Polish).

[28] Lemanowicz, J., Koper, J. (2012): Activity of phosphatase and the content of phosphorus in soil under selected crops fertilised with slurry. - Proceedings of ECOpole 6(1): 239243.

[29] Massawe, F., Mayes, S., Cheng, A. (2016): Crop diversity: an unexploited treasure trove for food security. - Trends in Plant Science 21(5): 365-368.

[30] Nannipieri, P., Kandeler, E., Ruggiero, P. (2002): Enzyme Activities and Microbiological and Biochemical Processes in Soil. - In: Burns, R. G., Dick, R. P. (eds.) Enzymes in the Environment. Activity, Ecology and Applications. Marcel Dekker, New York, pp. 1-33.

[31] Napora, A., Grobelak, A. (2014): Sewage sludge influence on microbiological and biochemical soil activity. - Engineering and Protection of Environmental 17(4): 619-630.

[32] Natywa, M., Selwet, M., Maciejewski, T. (2014): Effect of some agrotechnical factors on the number and activity soil microorganisms. - Fragmenta Agronomica 31(2): 56-63 (in Polish).

[33] Nardi, S., Pizzeghello, D., Schiavon, M., Ertani, A. (2016): Plant biostimulants: physiological responses induced by protein hydrolyzed-based products and humic substances in plant metabolism. - Scientia Agricola 73(1): 18-23.

[34] Niewiadomska, A. (2013): Assessment of the Impact of PRP SOL Fertiliser and Coinoculation on the Process Diazotrophy, Biological and Chemical Properties of Soil and the Crop Condition under Clover and Alfalfa Cultivation. - UP, Poznań (in Polish).

[35] Niewiadomska, A., Sulewska, H., Wolna-Maruwka, A., Ratajczak, K., Głuchowska, K., Waraczewska, Z., Budka, A. (2018a). An assessment of the influence of co-inoculation with endophytic bacteria and rhizobia, and the influence of PRP SOL and PRP EBV fertilisers on the microbial parameters of soil and nitrogenase activity in yellow lupine (Lupinus luteus L.) cultivation. - Polish Journal of Environmental Studies 27(6): 26872702.

[36] Niewiadomska, A., Sulewska, H., Wolna-Maruwka, A., Waraczewska, Z., Budka, A., Ratajczak, K. (2018b): An assessment of the influence of selected herbicides on the microbial parameters of soil in maize (Zea mays) cultivation. - Applied Ecology and Environmental Research 16(4): 4735-4752.

[37] Poole, P., Ramachandran, V., Terpolilli, J. (2018): Rhizobia: from saprophytes to endosymbionts. - Nature Reviews Microbiology 16(5): 291-303.

[38] Romanowicz, A., Krzepiłko, A. (2013): Volumetric determination of catalase activity in various organs of the primocane-fruiting polana variety of raspberry Rubus idaeus L. and in soil it is grown on. - Polish Journal Agronomy 15: 49-53 (in Polish).

[39] Rotaru, V. (2015): Responses of acid phosphatase activity on the root surface and rhizospheric soil of soybean plants to phosphorus fertilization and rhizobacteria application under low water supply. - Scientific Papers-Series A, Agronomy 58: 295-300.

[40] Saviozzi, A., Levi-Minzi, R., Cardelli, R., Riffaldi, R. (2001): A comparison of soil quality in adjacent cultivated, forest and native grassland soils. - Plant and Soil 233: 251259.

[41] Saviozzi, A., Cardelli, R., Levi-Minzi, R., Riffaldi, R. (2004): Evolution of biochemical parameters during composting of urban wastes. - Compost Science and Utilization 12(2): 153-160.

[42] Sawicka, A. (1983): The ecological aspects of dinitrogen fixation. - Annals of the University of Agriculture in Poznan. Scientific Dissertations 134: 1-57 (in Polish). 
[43] Selivanovskaya, S. Y., Latypova, V. Z., Gubaeva, L. A. (2006): Microbiological processes in gray forest soil treated with sewage sludge compost. - European Journal of Soil Science 39(4): 443-449.

[44] Stachowski, P. (2010): Evaluation of meteorological droughts in post-mining areas in Poland in Konin area. - Central Pomeranian Scientific Society for Environmental Protection. Annual Set the Environ. Protect. 12: 587.

[45] Stagnari, F., Maggio, A., Galieni, A., Pisante, M. (2017): Multiple benefits of legumes for agriculture sustainability: an overview. - Chemical and Biological Technologies in Agriculture 4(1): 1-13.

[46] Swędrzyńska, D., Zielewicz, W., Przybył, P., Starzyk, J. (2013): Effect of bio soil conditioner on microbial state and enzymatic activity of soil under Lolium perenne cultivation. - Grassland Science in Poland 16: 111-128.

[47] Symanowicz, B., Pala, J., Kalembasa, S. (2005): Influence of biological reduction of N2 on the uptake of nitrogen by goat's rue (Galega orientalis Lam.). Acta Scientiarum Polonorum. - Agricultura 4(2): 93-99 (in Polish).

[48] Szewczuk, C., Sugier, D. (2009): General characteristics and types of foliar fertilizers offered on the Polish market. - Annales Universitatis Mariae Curie-Skłodowska, Agricultura 64(1): 29-36.

[49] Szymczak, J., Kłódka, D., Smolik, B., Pawlica, M. (2011): Effect of cadmium salt on the activity of oxidative stress enzymes in soil and maize (Zea mays var. saccharata). Environmental Protection and Natural Resources 48: 210-215.

[50] Tabatabai, M. A., Bremner, J. M. (1969): Use of p-nitrophenyl phosphate for assay of soil phosphatase activity. - Soil Biology and Biochemistry 1(4): 301-307.

[51] Taran, N. Y., Gonchar, O. M., Lopatko, K. G., Batsmanova, L. M., Patyka, M. V., Volkogon, M. V. (2014): The effect of colloidal solution of molybdenum nanoparticles on the microbial composition in rhizosphere of Cicer arietinum L. - Nanoscale Research Letters 9(1): 289-297.

[52] Thalmann, A. (1968): Zur Methodik der Bestimmung der Dehydrogenase aktivität im Boden mittels triphenytetrazoliumchlorid (TTC). - Landwirtsch Forsch 21: 249-258.

[53] Utobo, E. B., Tewari, L. (2015): Soil enzymes as bioindicators of soil ecosystem status. Applied Ecology and Environmental Research 13(1): 147-169.

[54] Van Reeuwijk, L. P. (2002): Procedures for Soil Analysis. $6^{\text {th }}$ Ed. - ISRIC, Wageningen, Netherlands.

[55] Vernieri, P., Ferrante, A., Borghesi, E., Mugnai, S. (2006): Biostimulants: a tool for improving quality and yield (=Biostimolanti: uno strumento per migliorare la qualità delle produzioni). - Fertilitas Agrorum 1: 17-22.

[56] Vieira, R. F., Cardoso, E. J. B. N., Vieira, C., Cassini, S. T. A. (1998): Foliar application of molybdenum in common beans. I. Nitrogenase and reductase activities in a soil of high fertility. - Journal of Plant Nutrition 21: 169-180.

[57] Walter, H. (1976): Vegetation Zones and Climate. - PWRiL, Warszawa, pp. 26-31 (in Polish).

[58] Weisany, W., Raei, Y., Allahverdipoor, K. H. (2013): Role of some of mineral nutrients in biological nitrogen fixation. - Bulletin of Environment, Pharmacology and Life Sciences 2(4): 77-84.

[59] Zahran, H. H. (1999): Rhizobium-legume symbiosis and nitrogen fixation under severe conditions and in arid climate. - Microbiology and Molecular Biology Reviews 63(4): 968-989. 